Miguel Clemente

Adela Reig-Botella

Juan Carlos Prados

Área de Psicología Social. Departamento de Psicología. Universidad de A Coruña, España

Correspondence:

Miguel Clemente

Área de Psicología Social

Departamento de Psicología

Universidad de A Coruña - Campus de Elviña

15071 A Coruña, España

E-mail: miguel.clemente@udc.es

Received: $3 / 17 / 2014$

Approved: 10/12/2014

Article available from: www.scielo.br/rsp

\section{Alterations in psychosocial health of people affected by asbestos poisoning}

\section{Alteraciones de la salud psicosocial en afectados por intoxicación por amianto}

\begin{abstract}
OBJECTIVE: To analyze the state of psychosocial and mental health of professionals affected by asbestos.

METHODS: A cross-sectional study was conducted with 110 professionals working in the Ferrolterra region of Spain, who were affected by asbestos poisoning. This group was compared with a group of 70 shipyard workers with no manifestation of work-related diseases. All the participants were male with a mean age of 67 years. This study was conducted in 2013, between January and June, and used the SCL-90 questionnaire by Derogatis as its primary measure for research. This questionnaire consists of 9 variables that measure psychosomatic symptoms. In addition, an overall index of psychosomatic gravity was calculated. The participants were also asked two questions concerning their overall perception of feeling good. Data were analyzed by ANOVA and logistic regression.
\end{abstract}

RESULTS: Participants affected by asbestos poisoning showed high occurrence rates of psychological health variables such as somatization, obsessive-compulsive, interpersonal sensitivity, depression, anxiety, hostility, phobic anxiety, paranoid ideation, psychoticism, and global severity index.

CONCLUSIONS: Social interaction as a differentiating factor between workers affected by work-related chronic syndromes as compared to healthy participants will possibly aid in the development of intervention programs by improving the social network of affected individuals.

DESCRIPTORS: Asbestos, poisoning. Cost of Illness. Quality of Life. Mental Health. Occupational Diseases. Occupational Health. 


\section{RESUMEN}

OBJETIVO: Analizar el estado de salud psicosocial y mental de profesionales afectados por el amianto.

MÉTODOS: Estudio transversal con 110 profesionales en la comarca de Ferrolterra, España, afectadas por intoxicación por amianto; y un grupo de comparación de 70 trabajadores de astilleros, que no presentaban manifestación de enfermedades profesionales. Todos fueron del sexo masculino con edad promedio de 67 años. El estudio se llevó a cabo entre Enero y Junio de 2013. Para la realización de la investigación se empleó como instrumento el cuestionario SCL-90 de Derogatis. Este cuestionario está formado por nueve variables que miden la sintomatología psicosomática, y también, se calculó un índice global de gravedad psicosomática. Se les preguntó a los sujetos sobre su percepción global de sentirse bien. Se analizaron los datos mediante la técnica del Anova, y se realizó una regresión logística.

RESULTADOS: Los sujetos afectados por la intoxicación por amianto presentaron altos índices de alteración de su salud psicológica en variables como somatización, obsesión-compulsión, sensibilidad interpersonal, depresión, ansiedad, hostilidad, ansiedad fóbica, ideación paranoide, psicoticismo e indicador global de gravedad.

CONCLUSIONES: La interacción social como factor diferenciador entre trabajadores afectados por síndromes crónicos, debidos al trabajo, frente a los no afectados, permitirá desarrollar programas de intervención basados en el fomento de la red social de los afectados.

DESCRIPTORES: Asbestos. Envenenamiento. Costo de Enfermedad. Calidad de Vida. Salud Mental. Enfermedades Profesionales. Salud Laboral.

\section{INTRODUCTION}

Despite the global importance of constant health promotion, workers suffer from serious health problems arising from extreme conditions. For example, asbestos poisoning caused by occupational, domestic, or environmental exposure to asbestos. ${ }^{19}$

Occupational exposure is the greatest source of exposure to asbestos. ${ }^{17}$ The primary diseases associated with asbestos exposure are mesotheliomas, lung cancer, and asbestosis. ${ }^{9}$

Major depressive disorder is one of the diseases with the greatest negative impact on work productivity as well as the general state of mind. ${ }^{11}$ Participants with chronic physical diseases tend to have greater number and intensity of mood disorders. Prevention of skin-related diseases is one of the most investigated topics because it implies a serious public health concern. ${ }^{15,20,23,24,26}$ Moreover, occupational rhinitis has also been reported in the literature. ${ }^{1}$

The work by Maurel et $\mathrm{al}^{21}$ is of significance because its components form the self-designated national network of previous exposure to asbestos. Scientific literature does not always refer to the effects of asbestos in itself, but rather to a central issue within this effect such as the consequences of suffering from asthma due to work conditions. For example, Lowery et $\mathrm{al}^{18}$ specifically investigated quality of life. Similarly, Piirila et al ${ }^{22}$ addressed patients with asthma induced by diisocyanate, whereas Ward et $\mathrm{a}^{25}$ highlighted how suffering from chronic respiratory diseases represents a significant loss of work-related income.

From a psychological perspective, this study has opted to use the Symptom Checklist (SCL-90) by Derogatis \& Cleary $^{4}$ as its primary measure, as it is referenced both in its first article and in the later structural validation of the questionnaire. ${ }^{3}$ The SCL-90 has been used for research on the reduction of stress, specifically for anxiety, ${ }^{7,14}$ stress, ${ }^{7}$ and post-traumatic stress. ${ }^{2}$ Closer to our line of research, Drossman et $\mathrm{al}^{8}$ studied the forms of coping mechanisms used by patients suffering from chronic diseases. The deterioration of physical functions is 
linked with the deterioration of the social relationships of the affected such as in the case of individuals suffering from syncopes. ${ }^{16}$ Particularly in the area of occupational diseases, the study by Fex et al ${ }^{10}$ analyzes patients with rheumatoid arthritis.

The maritime sector has been one of the most affected by asbestos exposure. ${ }^{6,9,17}$ The Ferrol region in Spain is the European industrial city with the largest number of patients suffering from ailments caused by asbestos exposure, registering five annual cases of mesothelioma per 100,000 inhabitants. This ratio places the estuary of Ferrol at the same level as Glasgow or Liverpool. ${ }^{6,12}$

The objective of this study was to analyze the mental health of asbestos-affected professionals.

\section{METHODS}

A cross-sectional survey was conducted in 2013 in Ferrolterra, namely in the factories of Navantia and Astano, where an average of 600 workers affected by asbestos were concentrated. One hundred and eighty subjects participated in the, with 110 chronic patients affected by respiratory diseases caused by asbestos poisoning and 70 healthy subjects of the same age group. All the participants were male. It was an incidental and a non-probabilistic sample.

The participants considered to be intoxicated were radiologically classified, as established by the International Labor Organization (ILO), for pneumoconiosis. This classification is especially useful for detecting breathing diseases in professionals, as established by the Joint International Program ILO/World Health Organization (WHO) for the world eradication of silicosis and for the early detection of pneumoconiosis.

It was determined whether there were co-existent disorders. The existence of asbestosis, i.e., secondary diffuse interstitial pulmonary fibrosis due to inhalation of asbestos fibers was verified. The diagnosis was performed through the confirmation of the following requirements: existence of previous asbestos exposure; existence of latency periods $>15$ years; clinical, radiological, and functional findings suggesting diffuse interstitial disease; and dismissal of other causes of diffuse respiratory diseases. The participants of a subsample of patients showed respiratory functional alterations, including alterations associated with the interchange of hemopathological gases and the appearance of constrictive disorders. Nevertheless, these presented bilateral marked, calcified, pleural plates generally located in the pleura parietal. Restrictions of the obtrusive, restrictive, and mix types were found.

The fundamental research tool was the SCL-90 questionnaire, namely the Spanish adaptation and scoring. ${ }^{5}$
This test allows the following dimensions to be identified and evaluated: somatization, obsession-compulsion, interpersonal sensitivity, depression, anxiety, hostility, phobic anxiety, paranoid ideation, psychoticism, and the global severity index (GSI).

Sets of questions composed of the following sections were developed: sociodemographic identification, labor identification, scale SCL-90, and detection of overall energy levels (compared before and after suffering from the disease). The participants of both the subsamples were grouped by age. The affected participants were contacted with the help of patient associations. A comparison between healthy and affected individuals was possible with the support of the state company of Spanish shipyards, where the affected participants were employed. Both the groups were equally exposed to asbestos poisoning, although one of them developed the disease while the other showed no relevant symptoms. By the end of the survey, approximately $15.0 \%$ of the affected participants deceased while the participants from the non-affected group survived. The fact that both the subsamples were composed of workers exposed to asbestos, assured that from a methodological viewpoint, the influence of possible variables that might contaminate the results was avoided.

The applied detection system allows the determination of the presence of asbestosis, independent of whether the patients are chronically sick. On the other hand, the subsample of unaffected but exposed participants prevents occurrence of results determined by the chronic nature of the disease.

The study constituted of only two groups at the post measurement stage with selected variables. The control group was a convenience sample, while the one comprising affected participants represented the individuals who were alive at the time of the survey.

Descriptive statistics for all the dependent variables were calculated (Table 1).

The data were analyzed using the SPSS 18 program. First, descriptive statistics (mean/average and standard deviation) were calculated for each group (control and affected) within each variable. Second, an analysis of variables test (ANOVA) was performed for comparing the evaluated groups. Finally, a test of nonlinear logistic regression was performed to determine which variables were more explicative for each group (control and affected).

This study was approved by the Ethics Committee of the Universidad de A Coruña (University of A Coruña-Process 89), in 2012. No participant refused to participate and all the participants signed the informed consent. 
Table 1. Descriptive statistics of the health variables. Ferrolterra, Spain, 2013.

\begin{tabular}{|c|c|c|c|}
\hline Variable & & Mean/average & Standard deviation \\
\hline \multirow[t]{3}{*}{ Somatization } & Control & 17.7 & 6.5 \\
\hline & Affected & 28.6 & 11.0 \\
\hline & Total & 23.9 & 10.8 \\
\hline \multirow[t]{3}{*}{ Obsessive compulsion } & Control & 15.0 & 6.7 \\
\hline & Affected & 23.2 & 7.7 \\
\hline & Total & 19.9 & 8.3 \\
\hline \multirow[t]{3}{*}{ Interpersonal sensitivity } & Control & 12.0 & 7.1 \\
\hline & Affected & 16.1 & 6.7 \\
\hline & Total & 14.4 & 7.1 \\
\hline \multirow[t]{3}{*}{ Depression } & Control & 16.5 & 10.0 \\
\hline & Affected & 27.9 & 11.9 \\
\hline & Total & 23.1 & 12.4 \\
\hline \multirow[t]{3}{*}{ Anxiety } & Control & 11.9 & 6.7 \\
\hline & Affected & 19.8 & 9.1 \\
\hline & Total & 16.5 & 9.0 \\
\hline \multirow[t]{3}{*}{ Hostility } & Control & 8.6 & 3.3 \\
\hline & Affected & 11.1 & 4.7 \\
\hline & Total & 10.1 & 4.4 \\
\hline \multirow[t]{3}{*}{ Phobic anxiety } & Control & 5.8 & 4.6 \\
\hline & Affected & 11.4 & 6.1 \\
\hline & Total & 9.1 & 6.2 \\
\hline \multirow[t]{3}{*}{ Paranoid ideation } & Control & 6.2 & 5.4 \\
\hline & Affected & 10.9 & 5.8 \\
\hline & Total & 9.0 & 6.0 \\
\hline \multirow[t]{3}{*}{ Psychoticism } & Control & 9.5 & 6.5 \\
\hline & Affected & 17.3 & 7.9 \\
\hline & Total & 14.1 & 8.3 \\
\hline \multirow[t]{3}{*}{ Global severity index (GSI) } & Control & 1.4 & 0.6 \\
\hline & Affected & 2.1 & 0.8 \\
\hline & Total & 1.8 & 0.8 \\
\hline \multirow[t]{3}{*}{ Global energy level } & Control & 3.3 & 0.7 \\
\hline & Affected & 2.7 & 0.9 \\
\hline & Total & 2.9 & 0.9 \\
\hline \multirow[t]{3}{*}{ Global energy level compared before/after } & Control & 2.8 & 0.6 \\
\hline & Affected & 2.1 & 0.8 \\
\hline & Total & 2.3 & 0.8 \\
\hline
\end{tabular}

\section{RESULTS}

There was no homogeneity of variation in the following variables by means of the Levene test: Somatization $(\mathrm{F}=16.614$; sign. 0.000); Anxiety $(\mathrm{F}=8.506$; sign. 0.004); Hostility $(\mathrm{F}=9.432$; sign. 0.002$)$; GSI $(\mathrm{F}=7.584$; sign. 0.007); and General energy levels $(\mathrm{F}=9.803$; sign. 0.002). Analyses of non-homogeneous variations with the previously mentioned variables were performed. The procedure of homogeneous variations for the remaining variables was used (Table 2).
The study variables were statistically significant according to the ANOVA test, with values above the significance level of $1 / 1,000$. However, the study intended to determine which variables were more predictive at the time of determining to which group the participants belonged. For this, a logistic regression was performed. The omnibus tests on the coefficients allowed us to verify, using the Chi-square test, which variables were highly significant because the value of the model (Chi-square of 40.416 with $10 \mathrm{GL}$, $\alpha=0.000$ ) implied significance of $>1 / 1,000$. 
Table 2. Anova of the health variables. Ferrolterra, Spain, 2013.

\begin{tabular}{|c|c|c|c|c|c|c|}
\hline Variable & & Sum of squares & $\begin{array}{l}\text { Degrees of } \\
\text { freedom }\end{array}$ & $\begin{array}{l}\text { Root mean } \\
\text { square }\end{array}$ & Statistical F & Significance \\
\hline \multirow[t]{3}{*}{ Somatization } & Intergroup & 4648.414 & 1 & 4648.414 & 53.245 & 0.001 \\
\hline & Intragroup & 13793.829 & 158 & 87.303 & & \\
\hline & Total & 18442.244 & 159 & & & \\
\hline \multirow[t]{3}{*}{ Obsessive compulsion } & Intergrupos & 2787.655 & 1 & 2787.655 & 52.267 & 0.001 \\
\hline & Intragrupos & 9066.874 & 170 & 53.335 & & \\
\hline & Total & 11854.529 & 171 & & & \\
\hline \multirow[t]{3}{*}{ Interpersonal sensitivity } & Intergrupos & 709.375 & 1 & 709.375 & 15.052 & 0.001 \\
\hline & Intragrupos & 8058.972 & 171 & 47.128 & & \\
\hline & Total & 8768.347 & 172 & & & \\
\hline \multirow[t]{3}{*}{ Depression } & Intergrupos & 5162.879 & 1 & 5162.879 & 41.702 & 0.001 \\
\hline & Intragrupos & 19932.667 & 161 & 123.805 & & \\
\hline & Total & 25095.546 & 162 & & & \\
\hline \multirow[t]{3}{*}{ Anxiety } & Intergrupos & 2552.360 & 1 & 2552.360 & 38.069 & 0.001 \\
\hline & Intragrupos & 11129.616 & 166 & 67.046 & & \\
\hline & Total & 13681.976 & 167 & & & \\
\hline \multirow[t]{3}{*}{ Hostility } & Intergrupos & 262.286 & 1 & 262.286 & 14.709 & 0.001 \\
\hline & Intragrupos & 2977.797 & 167 & 17.831 & & \\
\hline & Total & 3240.083 & 168 & & & \\
\hline \multirow[t]{3}{*}{ Phobic anxiety } & Intergrupos & 1278.115 & 1 & 1278.115 & 41.717 & 0.001 \\
\hline & Intragrupos & 5147.185 & 168 & 30.638 & & \\
\hline & Total & 6425.300 & 169 & & & \\
\hline \multirow[t]{3}{*}{ Paranoid ideation } & Intergrupos & 888.653 & 1 & 888.653 & 28.050 & 0.001 \\
\hline & Intragrupos & 5354.061 & 169 & 31.681 & & \\
\hline & Total & 6242.713 & 170 & & & \\
\hline \multirow[t]{3}{*}{ Psychoticism } & Intergrupos & 2453.385 & 1 & 2453.385 & 45.284 & 0.001 \\
\hline & Intragrupos & 8885.145 & 164 & 54.178 & & \\
\hline & Total & 11338.530 & 165 & & & \\
\hline \multirow[t]{3}{*}{ Global severity index (GSI) } & Intergrupos & 8.582 & 1 & 8.582 & 15.339 & 0.001 \\
\hline & Intragrupos & 49.236 & 88 & 0.560 & & \\
\hline & Total & 57.818 & 89 & & & \\
\hline \multirow[t]{3}{*}{ General feeling of energy } & Intergrupos & 17.687 & 1 & 17.687 & 24.835 & 0.001 \\
\hline & Intragrupos & 124.630 & 175 & 0.712 & & \\
\hline & Total & 142.316 & 176 & & & \\
\hline \multirow{3}{*}{$\begin{array}{l}\text { General feeling of energy } \\
\text { compared before-after }\end{array}$} & Intergrupos & 15.730 & 1 & 15.730 & 24.349 & 0.001 \\
\hline & Intragrupos & 96.257 & 149 & 0.646 & & \\
\hline & Total & 111.987 & 150 & & & \\
\hline
\end{tabular}

The values in bold are more relevant at minor levels at $5 \%$.

The summary of the logistic regression model allowed us to obtain the correct percentage of classifications in the control group of $77.5 \%$, and of $80.0 \%$, in the case of affected participants. The correct classification was reflected by $78.9 \%$ of the participants for a cut-off point of 0.5 ; i.e., one could establish that the developed model showed good statistical prediction. The model shown in Table 3 is composed of a single variable, i.e., interpersonal sensitivity, with a significance of $1.0 \%$. The remaining variables are not significant below $(5 \%)$. 


\section{DISCUSSION}

The affected participants presented high indexes of alteration of mental health in comparison with unaffected participants. All the variables of the SCL-90 questionnaire were shown to be highly significant (Somatization, obsession compulsion, interpersonal sensitivity, depression, anxiety, hostility, phobic anxiety, paranoid ideation, psychoticism, and GSI. The two indicators included in the set, i.e., the global energy level and the global severity index, before and after the disease, show highly significant differences between the two groups. In addition, the verification of which variable (interpersonal sensitivity) allowed accurate classification of the subjects according to the group was relevant. This finding shows that the behavior of people around the affected subjects, i.e., those who are a part of their social network, becomes a main differential factor regarding to which group the participants belonged to.

These conclusions follow previous studies but they add a not yet contemplated nuance. Previous studies have emphasized on other variables that distinguish affected individuals rather than those who comprise the control sample. For example, Gadalla ${ }^{11}$ or, more recently, Hees, ${ }^{13}$ who reported major depression as the identifying key. The unaffected live with the fear that they can suffer from cancer in the future, which may lead us to think that dramatic differences would exist in all the variables in both the groups. This is due to the fact that the individuals belonging to the control group are workers of the same company ignoring being affected by any disease, i.e., no one from the control group developed cancer or any other asbestos-related disease. Notwithstanding, it is not surprising that there is a difference in practice. Drossman et $\mathrm{al}^{8}$ stressed how the patients with chronic diseases present a more negative perception of their well-being and their health and higher anxiety levels. This characterization implies more emotional decay and larger commitment on their health condition.

There has always been a situation of fear, and even if it does not imply suffering from a chronic disease, there are significant differences in all detected variables; hence, a number of studies have focused on posttraumatic stress.

The data from this study indicate that interpersonal sensitivity allows differentiating both the groups. If this fact supports most authors who have established a connection between quality of life and professional diseases, ${ }^{18,22}$ it allows making a complete turn on the conception of quality of life per se. This conception should not only focus on individual and clinical concerns but also social problems such as the quantity and quality of social relationships that the affected patients need.

Considering social interaction as a differentiating factor between workers affected by work-related chronic syndromes, in comparison with the unaffected, will allow the development of intervention programs based on fostering the social network of affected individuals. Therefore, one needs to incorporate quality-of-life tests in future studies, centered on the social interaction of the participants, an issue that moves research planning closer to the WHO recommendations.

Table 3. Integrant variables of the regression equation. Ferrolterra, Spain, 2013.

\begin{tabular}{|c|c|c|c|c|c|c|}
\hline Variable & $\begin{array}{c}\text { Beta Coefficient } \\
(\beta)\end{array}$ & $\begin{array}{l}\text { Standard } \\
\text { error }\end{array}$ & Wald Test & $\begin{array}{l}\text { Degrees of } \\
\text { freedom }\end{array}$ & Significance & $\begin{array}{l}\text { Exponential } \\
\text { of the beta } \\
\text { coefficient }\end{array}$ \\
\hline Somatization & 0.036 & 0.089 & 0.158 & 1 & 0.691 & 1.036 \\
\hline Obsessive compulsion & 0.170 & 0.099 & 2.945 & 1 & 0.086 & 1.185 \\
\hline Interpersonal sensitivity & -0.368 & 0.148 & 6.192 & 1 & 0.013 & 0.692 \\
\hline Depression & 0.148 & 0.118 & 1.561 & 1 & 0.211 & 1.159 \\
\hline Anxiety & -0.097 & 0.129 & 0.567 & 1 & 0.452 & 0.907 \\
\hline Hostility & -0.163 & 0.145 & 1.257 & 1 & 0.262 & 0.850 \\
\hline Phobic anxiety & 0.061 & 0.128 & 0.225 & 1 & 0.636 & 1.062 \\
\hline Paranoid ideation & -0.017 & 0.155 & 0.012 & 1 & 0.911 & 0.983 \\
\hline Psychoticism & 0.258 & 0.158 & 2.672 & 1 & 0.102 & 1.294 \\
\hline Constant & -2.220 & 1.066 & 4.336 & 1 & 0.037 & 0.109 \\
\hline
\end{tabular}

The values in bold are more relevant at minor levels at $5 \%$. 


\section{REFERENCES}

1. Airaksinen LK, Luukkonen RA, Lindstrom I, Lauerma AI, Toskala EM. Long-term exposure and health-related quality of life among occupational rhinitis. J Occup Environ Med. 2009;51(11):1288-97. DOI:10.1097/JOM.0b013e3181b9b242

2. Davidson RJT, Book SW, Colket JT, Tupler LA, Roth S, David D, et al. Assessment of a New Self-Rating scale for posttraumatic stress disorder. Psychol Med. 1997;27(1):153-60. DOI:10.1017/S0033291796004229

3. Derogatis LR, Rickels K, Rock AF. SCL-90 and MMPI. Step in validation of a new self-report scale. Brit J Psychiatry. 1976;128:280-9. DOI:10.1192/bjp.128.3.280

4. Derogatis LR, Cleary PA. Factorial invariance across gender for primary symptom dimensions of SCL-90. Brit J Soc Clin Psychol. 1977;16:347-56. DOI:10.1111/j.2044-8260.1977.tb00241.x

5. Derogatis LR, Cleary PA. Confirmation of Dimensional Structure of SCL-90: a study in construct-validation. J Clin Psychol. 1977;33(4):981-9. DOI:10.1002/1097-4679(197710)33:4<981::AID-JCLP 2270330412>3.0.CO;2-0

6. Diego C, Velasco-García MI, Cruz, MJ, Calvo U, De los Reyes R, Mejuto MJ, et al. Intrapulmonary asbestos concentrations in shipyard workers exposed to asbestos in El Ferrol, Spain. Eur Resp J. 2011;38(Suppl 55):1069.

7. Dooley J, Wilson J, Anderson V. Stress and depression of facing death: Investigation of psychological symptoms in patients with mesothelima. Autr J Psychol. 2010;62(3):160-8. DOI:10.1080/00049530903510757

8. Drossman DA, Leserman J, Li ZM, Mitchell CM, Zagami EA, Patrick DL. The Rating form of IBD patient concerns. A new measure of health-status. Psychosomatic Med. 1991;53(6):701-12. DOI:10.1097/00006842-199111000-00010

9. Ferrer J, Cruz MJ. Amianto, factor de riesgo del cáncer de pulmón. Med Clin. 2008;130(9):334-5. DOI:10.1157/13117354

10. Fex E, Larsson, BM, Nived K, Eberhardt K. Effect of rheumatoid arthritis on work status and social and leisure time activities in patients followed 8 years from onset. J Rheumatol. 1998;25(1):44-50.

11. Gadalla T. Association of Comorbid mood disorders and chronic illness with disability and quality of life in Ontario, Canada. Chronic Dis Canada. 2008;28(4):148-54.

12. García-Gómez M, Menéndez-Navarro A, Castañeda-López, R. Incidence of Asbestosis and other Benign Lung Diseases: Spain, 1962-2010. Rev Española Salud Publica. 2012;86(6):613-25.

13. Hees HL, Koeter MWJ, De Vries G, Ooteman W, Schene AH. Effectiveness of adjuvant occupational therapy in employees with depression: design of a randomized controlled trial. BMC Public Health. 2010;10:558. DOI:10.1186/1471-2458-10-558

14. Kabatzinn J, Massion AO, Kristeller J, Peterson LG, Fletcher, KE, Pbert L, et al. Effectiveness of a mediation-based stress reduction program in the treatment of anxiety disorders. Am J Psychiatry. 1992;149(7):936-43.

15. Kezic S, Visser MJ, Verberk MM. Individual Susceptibility to Occupational Contact Dermatitis. Industrial Health. 2009;47(5):469-78. DOI:10.2486/indhealth.47.469

16. Linzer M, Pontinen M, Gold DT, Divine GW, Felder A, Brooks WB. Impairment of physical and psychosocial function in recurrent syncope. J Clin Epidemiol. 1991;44(10):1037-43. DOI:10.1016/0895-4356(91)90005-T

17. Losilla J. Trabajos con riesgo de exposición al amianto. Energ Minas. 2010;8:34-9.

18. Lowery EP, Henneberger PK, Rosiello R, Sama SR, Preusse P, Milton DK. Quality of life of adults with workplace exacerbation of Asthma. Qual Life Res. 2007;16(10):1605-13. DOI:10.1007/s11136-007-9274-5

19. Luis G, Hernández C, Rubio C, Frías I, Gutiérrez A, Hardisson A. Toxicología del asbesto. Cuad Med Forense. 2009;15(57):207-13.

20. Matterne U, Diepgen TL,Weisshaar E. Effects of a Health-Educational and Psychological Intervention on socio-cognitive determinants of skin protection behavior in individuals with occupational dermatoses. Int Arch Occup Environ Health. 2010;83(2):183-9. DOI:10.1007/s00420-009-0448-z

21. Maurel M, Stoufflet A, Thorel L, Berna V, Gislard A, Letourneux $M$, et al. Fear associated with cancer distress in the Asbestos Post-Exposure Survey (APEXS). Am J Industr Med. 2009;52(4):288-96. DOI:10.1002/ajim.20672

22. Piirila PL, Keskinen HM, Luukkonen R, Salo SP, Tuppurainen M, Nordman H. Work, unemployment and life satisfaction among patients with diisocyanate induced asthma. A prospective study. J Occup Health. 2005;47(2):112-8. DOl:10.1539/joh.47.112

23. Potocka A, Turczyn-Jablonska K, Kiec-Swierczynska M. Self-Image and quality of life of dermatology patients. Int J Occup Med Environ Health. 2008;21(4):309-17. DOI:10.2478/v10001-008-0034-8

24. Van Gils RF, Van Der Valk PGM, Bruynzeel D, Coenraads PJ, Boot CRL, Van Mechelen W, et al. Integrated, multidisciplinary care for hand eczema: design of a randomized controlled trial and cost-effectiveness study. BMC Public Health. 2009;9:438-46. DOI:10.1186/1471-2458-9-438

25. Ward MM, Javitz HS, Smith WM, Wham MA. Lost income and work limitations in persons with chronic respiratory disorders. J Clin Epidemiol. 2002;55(3):260-8. DOI:10.1016/S0895-4356(01)00468-1

26. Weisshaar E, Radulescu M, Soder S, Apfelbacher CJ, Bock $M$, Grundmann JU, et al. Secondary individual prevention of occupational skin diseases in health care workers, cleaners and kitchen employees: aims, experiences and descriptive results. Int Arch Occup Environ Health. 2007;80(6):477-84. DOI:10.1007/s00420-006-0154-z 